\title{
EVALUASI KINERJA APARAT DALAM PELAYANAN PEMBUATAN \\ PENGANTAR E-KTP DI KELURAHAN MAMASA \\ KECAMATAN MAMASA KABUPATEN MAMASA
}

\author{
Richard $^{1}$, Rustan IR², M. Syariat Tajuddin ${ }^{3}$ \\ ${ }^{1}$ Prodi Ilmu Pemerintahan, Fakultas Ilmu-ilmu Sosial dan Ilmu Pemerintahan \\ Universitas Al Asyariah Mandar \\ Email: richard01@gmail.com \\ ${ }^{1}$ Prodi Ilmu Pemerintahan, Fakultas Ilmu-ilmu Sosial dan Ilmu Pemerintahan \\ Universitas Al Asyariah Mandar \\ Email: rustan.irta17@gmail.com \\ 1Prodi Ilmu Pemerintahan, Fakultas Ilmu-ilmu Sosial dan Ilmu Pemerintahan \\ Universitas Al Asyariah Mandar \\ Email: muhsyariat@gmail.com
}

\section{ABSTRACT}

This study aims to determine the performance evaluation of officers in the service of making e-KTP introductions in Mamasa Village, Mamasa District, Mamasa Regency. The research method used is descriptive research with a qualitative approach. The results showed that the performance of the Mamasa village apparatus was good but still needed to be improved in providing services to the community. In addition, the community expects the quality of public services to increase in the form of services that are fast, easy, fair, with legal certainty, transparent, safe, precise, free of charge, and accountable. In terms of the identity card service, the community wants a truly quality service.

ABSTRAK

Penelitian ini bertujuan untuk mengetahui evaluasi kinerja aparat dalam pelayanan pembuatan pengantar e-KTP di Kelurahan Mamasa Kecamatan Mamasa Kabupaten Mamasa. Metode penelitian yang digunakan adalah penelitian deskriptif dengan pendekatan kualitatif. Hasil penelitian menunjukkan bahwa kinerja aparat kelurahan mamasa sudah baik tapi masih perlu ditingkatkan dalam memberikan pelayanan kepada masyarakat, selain itu, masyarakat mengharapkan semakin meningkatnya kualitas pelayanan publik dalam wujud pelayanan yang cepat, mudah, berkeadilan, berkepastian hukum, transparan, aman, tepat, tidak mengumut biaya, dan dapat dipertanggung jawabkan. Dalam hal pelayanan Kartu Tanda Penduduk, masyarakat menginginkan pelayanan yang benar-benar berkualitas.

Kata Kunci: Pelayanan, Evaluasi Kinerja, e-KTP. 


\section{PENDAHULUAN}

Dengan diberlakukannya Undang-undang Nomor 32 tahun 2004 yang kemudian direvisi menjadi Undang-undang Nomor 23 tahun 2014 tentang Pemerintahan Daerah, bangsa Indonesia mengalami perubahan yang sangat mendasar dari berbagai bidang termasuk di dalam penyelenggaraan Pemerintahan. Undang-undang Nomor 23 tahun 2014 memberikan kewenangan yang sangat luas kepada Pemerintah Daerah di dalam menyelenggarakan pemerintahannya. Sesuai dengan hal tersebut di atas, Pemerintah Daerah mengemban tugas yang sangat besar dari seluruh aspek kinerja birokrasi pemerintahan pada umumnya, sehingga perlu adanya kontribusi yang nyata dari Pemerintah Daerah.

Undang-undang Nomor 23 tahun 2014 yang sarat dengan isu strategi berupa kelembagaan, sumber daya manusia berupa aparatur pelaksana, jaringan kerja serta lingkungan kondusif yang terus berubah merupakan sebuah tantangan bagi Pemerintah Daerah untuk meningkatkan kinerja dalam mencapai tujuan pelayanan kepada masyarakat. Undang-undang ini diidentifikasi di antaranya adalah menempatkan pemerintahan kecamatan dan kelurahan sebagai perangkat daerah otonom, yaitu Daerah Kabupaten dan Daerah Kota. Dengan kata lain, pemerintahan kecamatan menempati posisi sebagai kepanjangan tangan pemerintah daerah otonom (desentralisasi), dan bukan sebagai aparat dekonsentrasi.

Kinerja suatu birokrasi publik merupakan suatu isu yang sangat aktual yang terjadi pada masa sekarang ini. Masyarakat masih memandang kinerja dari birokrasi publik pada saat ini belum bisa memberikan rasa kepuasan yang tinggi, sehingga menyebabkan penyelenggaraan pemerintahan menjadi sorotan yang tajam, terutama dalam aspek transparansi, akuntabilitas, efisiensi dan efektifitas. Hal tersebut disebabkan masyarakat mulai kritis dalam memonitor dan mengevaluasi manfaat serta nilai yang diperoleh atas pelayanan dari instansi pemerintah. Disisi lain, pengukuran keberhasilan maupun kegagalan instansi pemerintah dalam menjalankan tugas pokok dan fungsinya sulit dilakukan secara obyektif, yang dapat menginformasikan tingkat keberhasilan secara obyektif dan terukur dari pelaksanaan program-program disuatu instansi pemerintah.

Informasi mengenai kinerja aparatur dan faktor-faktor yang ikut berpengaruh terhadap kinerja aparatur sangat penting untuk diketahui, 
sehingga pengukuran kinerja aparat hendaknya dapat diterjemahkan sebagai suatu kegiatan evaluasi untuk menilai atau melihat keberhasilan dan kegagalan pelaksanaan tugas dan fungsi yang dibebankan kepadanya. Oleh karena itu evaluasi kinerja merupakan analisis interpretasi keberhasilan dan kegagalan pencapaian kinerja.

Kinerja sangat penting bagi sebuah organisasi atau perusahaan dalam upaya mencapai tujuannya. Dalam konteks pengembangan sumber daya manu ia kinerja seorang karyawan dalam sebuah organisasi sangat dibutuhkan untuk mencapai kinerja yang baik bagi karyawan itu sendiri dan juga untuk keberhasilan perusahaan. Kinerja adalah hasil atau tingkat keberhasilan seseorang secara keseluruhan selama periode tertentu di dalam melaksanakan tugas dibandingkan dengan berbagai kemungkinan, seperti standar hasil kerja, target atau sasaran atau kriteria yang telah ditentukan terlebih dahulu dan telah disepakati bersama dan merupakan suatu fungsi dari motivasi dan kemampuan untuk menyelesaikan tugas atau pekerjaan. Kesediaan dan keterampilan seseorang tidaklah cukup efektif untuk mengerjakan sesuatu tanpa pemahaman yang jelas tentang apa yang akan dikerjakan dan bagaimana mengerjakan.

Kinerja organisasi yang telah dilaksanakan dengan tingkat pencapaian tertentu tersebut seharusnya sesuai dengan misi yang telah ditetapkan sebagai landasan untuk melakukan tugas yang diemban. Dengan demikian kinerja kemajuan pembangunan (performance) merupakan tingkat pencapaian hasil (Keban, 2004: 192).

Hal yang terjadi pada kinerja pegawai dalam pelayanan Pengantar EKTP di Kantor Kelurahan Mamasa Kabupaten Mamasa masih lamban dan kurang efektif yaitu kurangnya petugas/pegawai yang memiliki pengetahuan atau kemampuan di bidangnya dimana kualitas organisasi sangat tergantung dari sejauh mana sumberdaya manusia atau pegawainya dapat menyelesaikan tugas dan kegiatannya seefektif mungkin. Dalam hal pelayanan, dapat dikatakan berkualitas apabila hal tersebut dapat diselenggarakan sesuai pada waktu yang telah ditentukan, salahsatu faktor penghambat yang terjadi dikelurahan mamasa kurangnya fasilitas yang digunakan oleh para pegawai, yang digunakan di kelurahan mamasa tidak tersedia srana dan pra sarana komputer yang salahsatu faktor pendukung untuk fungsi aparat kelurahan.

\section{METODE PENELITIAN}

Jenis Penelitian yang penulis pergunakan dalam penelitian ini adalah jenis penelitian hukum sosiologis/empiris. Penelitian empiris adalah penelitian yang bertolak dari data empirik yang berakhir dengan penemuan. (Middlerange theory maupun grand theory); dimana kebenaran ditentukan, reabilitas 
dan validitas data dikumpulkan, diklasifikasikan, dan diinterprestasikan. Penelitian Empiris dimasudkan sebagai usaha mendekati masalah yang diteliti dengan sifat hukum yang sesuai dengan kenyataan yang dihadapi dalam masyarakat (Hilman Hadikusuma, 1995 : 61)

\section{HASIL PENELITIAN}

Pelayanan publik yang dilakukan oleh pemerintah merupakan tugas pokok, selain tugas-tugas pembangunan dan pemerintahan yang menjadi tanggungjawabnya. Pelayanan administrasi kependudukan merupakan salah satu tugas yang harus dilaksanakan. Seperti dalam pengurusan Kartu Tanda Penduduk (E-KTP) walau kelihatannya bagi sebagian masyarakat tidak begitu penting karena belum saatnya mereka memerlukan. Namun bagi masyarakat tertentu malah begitu penting, karena sangat diperlukan untuk memperoleh akses pelayanan lain. Dalam hal pelayanan Kartu Tanda Penduduk pemerintah telah menyiapkan peraturan perundang-undangan yang meliputi prosedur, biaya dan lain-lain.

\section{Profesionalisme Kerja Pegawai}

Profesionalisme pegawai sangat ditentukan oleh tingkat kemampuan pegawai yang tercermin melalui perilakunya sehari-hari dalam organisasi. Tingkat kemampuan pegawai yang tinggi akan lebih cepat mengarah kepada pencapaian tujuan organisasi yang telah direncanakan sebelumnya, sebaliknya apabila tingkat kemampuan pegawai rendah kecenderungan tujuan organisasi yang akan dicapai akan lambat bahkan menyimpang dari rencana semula. Dan istilah kemampuan dapat juga dipergunakan untuk menunjukkan apa yang akan dapat dikerjakan oleh seseorang, bukan apa yang telah dikerjakan oleh seseorang.

Dalam hal ini kemampuan dalam mepergunakan peralatan yang ada dalam mendukung pekerjaan yaitu proses pembuatan E-KTP dan kesiapan dalam pelaksanaan pelayanan pengurusan E-KTP yaitu disiplin dalam memulai dan menyelesaikan pekerjaannya, mentaati segala peraturan yang melandasi bidang pekerjaannya, sikap aparatur dalam memberikan pelayanan kepada masyarakat.

1) Kemahiran dalam mempergunakan peralatan yang ada dalam mendukung pekerjaan, yaitu proses pembuatan Kartu Tanda Penduduk.

Kemampuan pegawai dalam mempergunakan peralatan yang ada dalam mendukung pekerjaan, yaitu proses pembuatan Kartu Tanda Penduduk sudah cukup mahir. Seperti penguasaan teknologi komputer dalam proses percetakan E-KTP, namun sayangnya belum ada teknisi yang mampu memperbaiki mesin 
pencetak E-KTP saat rusak. Hal ini tentu menghambat proses pembuatan EKTP.

2) Kesiapan dalam pelaksanaan pelayanan pengurusan E-KTP yaitu disiplin dalam memulai dan menyelesaikan pelayanan

Kesiapan pegawai dalam pelaksanaan pelayanan pengurusan E-KTP yaitu disiplin dalam memulai dan menyelesaikan pelayanan sudah baik. Hal ini bisa dilihat dari pendapat masyarakat yang menyatakan pegawai selalu datang ke kantor tepat waktu. Hal ini diharapkan mampu memberikan kualitas pelayanan yang baik demi meningkatkan kepuasan pada masyarakat dalam pelayanan E-KTP.

3) Mentaati Segala Peraturan Yang Melandasi Bidang Pekerjaan

Para pegawai Kelurahan Mamasa dalam mentaati segala peraturan yang melandasi bidang pekerjaan sudah baik. Dalam melaksanakan tugas pengurusan Kartu Tanda Penduduk dengan ketentuan yang ada yaitu memberikan kemudahan bagi masyarakat dalam mengurusnya yaitu prosedur pengurusannya. Hal inilah yang diharapakan masyarakat yaitu kemudahan dalam proses pengurusan Kartu Tanda Penduduk.

4) Sikap aparatur dalam memberikan pelayanan kepada masyarakat

Sikap yang dilakukan pegawai Kelurahan Mamasa dalam melayani masyarakat adalah dengan menerima dan ramah terhadap masyarakat. Dengan sikap ramah dan sopan, pembicaraan yang wajar dalam arti tidak dibuat-buat, cukup jelas, tidak menimbulkan keraguan, disampaikan dengan terbuka. Dengan sikap aparatur yang seperti itu maka akan memperlancar proses pelayanan pengurusan Kartu Tanda Penduduk, dengan sikap ini masyarakat akan merasa puas dan dihargai.

\section{Kejelasan Pelayanan}

Kejelasan ini sangat penting dalam pelayanan publik, karena indikator ini dapat mempengaruhi kepercayaan masyarakat terhadap kinerja aparatur pemerintah Kelurahan yaitu meliputi prosedur atau tata cara pelayanan EKTP, persyaratan pelayanan, baik teknis atau administratif, rincian biaya atau tariff pelayanan dan tata cara pembayarannya, aparatur yang menerima keluhan masyarakat.

Menurut Budiono (2003 : 68-70), arti kejelasan dan kepastian adalah halhal yang berkaitan dengan:

a) Prosedur atau tata cara pelayanan umum;

b) Persyaratan pelayanan umum, baik teknis maupun administratif;

c) Unit kerja dan atau yang berwenang dan bertanggungjawab dalam memberikan pelayanan umum; 
d) Rincian/biaya tarif pelayanan umum dan tata cara pembayarannya;

e) Hak dan Kewajiban, baik bagi pemberi pelayanan maupun penerima pelayanan umum berdasarkan bukti-bukti penerima permohonan/ kelengkapannya, sebagai alat untuk memastikan pemprosesan pelayanan umum;

f) Pejabat yang menerima keluhan masyarakat.

Adapun pelayanan yang diberikan kepada masyarakat sudah ditetapkan, melalui prosedur kerja. Aparatur Kelurahan telah mengetahui dengan jelas cara pengurusannya, dengan demikian aparatur pemerintah Kelurahan dapat menyelesaikan pekerjaannya dengan baik.

1) Pelayanan yang merata dan sama tanpa membeda-bedakan status dan kedudukan

Pelayanan pemerintah sebagai pelaku organisasi publik harus bersifat netarl dab tidak memihak. Pada dasarnya setiap orang berhak mendapatkan kesempatan dan pelayanan yang sama. Hal ini harus perlu dilaksanakan oleh aparatur dalam memberikan pelayanan kepada setiap orang, dengan itu masyarakat akan merasa puas akan pelayanan yang diberikan oleh aparatur pemerintah.

Mengenai pelayanan yang diberikan oleh pegawai Kelurahan Mamasa kepada masyarakat yang melakukan aktivitas pengurusan Kartu Tanda Penduduk adalah sama merata tanpa memandang golongan dan status. Hal ini disebabkan oleh adanya profesionalisme para aparatur dalam melaksanakan tugas-tugasnya serta perannya sesuai dengan tugas yang diemban. Dengan sikap seperti ini akan merubah cara pandang masyarakat kepada pemerintah, sehingga masyarakat merasa nyaman dan dihargai didalam proses pengurusan Kartu Tanda Penduduk.

Tetapi ada anggapan dari warga masyarakat yang menyatakan berbeda antara kenal orang dalam dan tidak. Namun hal itu dibantah oleh Pemerintah Kelurahan Mamasa. Pemerintah Kelurahan Mamasa menyatakan kalau persyaratan dan dokumen pengurusan E-KTP sudah lengkap, tentu akan segera diproses. Jadi pihak Pemerintah Kelurahan tidak membeda-bedakan antara yang kenal dan tidak.

2) Tersedia saranan pelayanan yang memadai dalam pengurusan E-KTP

Pemerintah Kelurahan Mamasa sudah memberikan sarana kepada masyarakat seperti televisi disaat masyarakat menunggu proses pelayanan, tersedianya sarana bacaan seperti koran dan tersedianya air minum bagi masyarakat. Namun masyarakat masih sedikit mengeluh dengan ruang tunggu yang sempit dan kurangnya sarana tempat duduk bagi masyarakat dalam 
proses pelayanan. Tentu hal ini harus menjadi perhatian bagi Pemerintah Kelurahan Mamasa untuk meningkatkan kepuasan pada masyarakat.

3) Pelayanan dengan cepat dan tepat sesuai dengan waktu yang telah ditentukan yaitu prosedur/tata cara pengurusan E-KTP

Pemerintah Kelurahan Mamasa sudah berusaha memberikan pelayanan dengan cepat dan tepat kepada masyarakat. Namun ada beberapa masyarakat yang sedikit mengeluh karena harus menunggu beberapa hari dalam proses percetakan E-KTP. Dan Pemerintah Kelurahan Mamasa berusaha untuk semaksimal mungkin memberikan pelayanan kepada masyarakat dalam proses pelayanan E-KTP dengan baik.

\section{4) Rincian biaya/tarif pengurusan E-KTP}

Munculnya keluhan-keluhan mengenai kualitas pelayanan publik dan semrawutnya penyelenggaraan pelayanan publik disebabkan karena prosedur layanan tidak jelas atau sengaja dibuat abu-abu sehingga menjadi area yang subur bagi tumbuhnya praktek penyelewengan. Persoalan yang timbul di masyarakat adalah penundaan yang berlarut, penyimpangan prosedur dan permintaan imbalan. Maka masyarakat menuntut tanggung jawab pelayanan dan peningkatan kinerja pelayanan publik semakin baik.

Biaya pelayanan adalah segala biaya dan rinciannya, dengan nama atau sebutan apapun, sebagai imbalan atas pemberian pelayanan umum yang besaran dan tata cara pembayarannya ditetapkan oleh pejabat berwenang. Kepastian dan rincian biaya pelayanan publik harus diinformasikan secara jelas.

Adapaun biaya/tarif pengurusan Kartu Tanda Penduduk belum ditetapkan dalam Peraturan Daerah yaitu masyarakat tidak dibebankan untuk mengeluarkan biaya dalam pengurusan Kartu Tanda Penduduk dengan tidak dipungut biaya, dapat digratiskan kepada seluruh lapisan masyarakat.

Biaya/tarif pengurusan E-KTP di Kantor Pemerintahan Kelurahan Mamasa tidak dipungut biaya kepada masyarakat. Namun Pemerintah Kelurahan membantah bila ada masyarakat yang membayar berkas lengkap langsung diproses dengan cepat. Pihak Pemerintah Kelurahan Mamasa mengakui kalau ada masyarakat yang memberi biaya tetapi pihak kelurahan tetap tidak menerima biaya tersebut.

\section{Ketepatan Waktu Pelayanan}

Yang dimaksud dengan ketepatan waktu adalah dalam pelaksanaan pelayanan umum dapat diselesaikan dalam kurun waktu yang telah ditentukan (Boediono, 2003 : 69). Mengenai ketepatan waktu dalam suatu proses administrasi pemerintahan seharusnya ada ketentuan untuk penyelesaian suatu 
pekerjaan yang prinsipnya cepat, tepat sasaran, dan tidak berbelit-belit serta memberikan kesan yang baik bagi masyarakat.

Waktu penyelesaian pelayanan adalah jangka waktu penyelesaian suatu pelayanan publik mulai dari dilengkapinya atau dipenuhinya persyaratan teknis dan atau persyaratan administratif sampai dengan selesainya suatu proses pelayanan. Kepastian dan kurun waktu penyelesaian pelayanan publik harus diinformasikan secara jelas.

Beberapa masyarakat menganggap pengurusan E-KTP di Kantor Kelurahan Mamasa sulit dan berbelit-belit. Tetapi anggapan itu di tepis oleh pegawai Kelurahan Mamasa. Hal itu disebabkan karena masyarakat tidak mengetahui prosedur dan tata cara pengurusan E-KTP. Hal itu menandakan informasi baru mengenai pengurusan E-KTP tidak serta merta diketahui oleh masyarakat luas di Kelurahan Mamasa .

\section{Kelengkapan Sarana dan Prasarana}

Dalam Keputusan Menteri Pendayagunaan Aparatur Negara No. 63 Tahun 2003 berdasarkan sarana-prasarana yaitu penyediaan sarana dan prasarana pelayanan yang memadai oleh penyelenggaraan pelayanan publik. Sarana prasaranan tersebut meliputi tersedia informasi yang memadai mengenai pengurusan Kartu Tanda Penduduk, tersedia loket atau kotak pengaduan untuk menampung keluhan masyarakat, tersedia ruang tunggu yang nyaman, toilet yang bersih dan lain-lain.

1) Tersedianya informasi mengenai pengurusan E-KTP

Dari hasil wawancara dengan informan, dapat disimpulkan bahwa Pemerintah Kelurahan Mamasa tentang Pengurusan Kartu Tanda Penduduk tidak secara langsung disosialisasikan kepada masyarakat, namun informasi tantang tata cara pengurusan Kartu Tanda Penduduk bisa didapat di Kantor Kelurahan ini, bahkan di tingkat Kelurahan/Kelurahan. Adanya perubahan dalam pengurusan E-KTP baru telah diberikan kepada Kelurahan/Kelurahan untuk disampaikan kepada masyarakat. Beberapa masyarakat yang tidak mengetahui informasi tentang perubahan pengurusan E-KTP, mengindikasikan kalau Pemerintah Kelurahan belum maksimal dalam mensosialisasikan tentang perubahan informasi pengurusan Kartu Tanda Penduduk.

2) Tersedianya ruang tunggu yang nyaman

Dari hasil wawancara dengan informan, tersedianya ruang tunggu bagi masyarakat ternyata belum merasa nyaman dalam pengurusan pelayanan. Ruangan yang kurang luas dan jumlah tempat duduk yang kurang tentu membuat masyarakat kurang nyaman. Pemerintah Kelurahan Mamasa harus memperhatikan tersedianya saranan ruang tunggu yang kurang nyaman bagi 
masyarakat saat ini. Hal ini untuk meningkatkan kepuasan pada masyarakat dalam memberikan pelayanan.

3) Tersedia Kotak/Loket pengaduan untuk menampung keluhan masyarakat

Tersedianya Kotak/Loket pengaduan di Pemerintah Kelurahan Mamasa untuk menampung keluhan masyarakat sudah ada sejak dulu. Namun dari hasil wawancara dengan informan, masyarakat enggan memberikan keluhankeluhan melalui Kotak/Loket yang sudah disediakan. Masyarakat hanya mengharapkan kalau datang mengurus Pelayanan segera dilayani dan tidak dipersulit

\section{KESIMPULAN}

Berdasarkan uraian hasil penelitian dan pembahasan, maka dalam penulisan ini dapat ditarik kesimpulan bahwa kinerja aparat Kelurahan Mamasa sudah baik tapi masih perlu ditingkat dalam memberikan pelayanan kepada masyarakat, Masyarakat mengharapkan dalam penyelenggaraan pelayanan publik antara lain semakin meningkatnya kualitas pelayanan publik dalam wujud pelayanan yang cepat, mudah, berkeadilan, berkepastian hukum, transparan, aman, tepat, tidak mengumut biaya, dan dapat dipertanggung jawabkan. Dalam hal pelayanan Kartu Tanda Penduduk, masyarakat menginginkan pelayanan yang benar-benar berkualitas. Hal ini bisa dilihat dari hasil laporan pada informan dalam wawancara. Kualitas pelayanan sudah dikatakan baik bisa dilihat dari aspek profesionalisme yang meliputi kemampuan pegawai dalam mempergunakan peralatan, aspek mentaati segala peraturan yang melandasi bidang pekerjaan, aspek kejelasan yang meliputi prosedur pelayanan yang baik serta rincian biaya atau tarif pembuatan Kartu Tanda Penduduk yang tidak dipungut (Pungli) kepada seluruh lapisan masyarakat Kelurahan Mamasa

\section{SARAN}

Walaupun kualitas pelayanan Kartu Tanda Penduduk sudah bisa dikatakan baik, namun ada beberapa hal yang perlu sedikit dibenahi untuk meningkatkan kualitas pelayanan pada masyarakat, seperti upaya penambahan sarana dan prasarana (komputer, mesin cetak, dll).

Pihak Pemerintah Kelurahan dapat menyebarluaskan brosur tentang prosedur pelayanan Kartu Tanda Penduduk yang telah diterbitkan oleh Dinas Catatan Sipil dan Kependudukan Kabupaten Mamasa agar masyarakat mengetahui prosedur pengurusannya dan agar tidak menimbulkan kesan yang berbelit-belit. Pemerintah Kelurahan Mamasa dapat memberikan informasi kepada masyarakat untuk menyampaikan atau memberikan surat apabila ada 
keluhan-keluhan di kotak/loket yang telah disediakan. Hal ini dimaksudkan agar para pegawai dapat mengevaluasi kekurangan-kekurangan dan terus meningkatkan kualitas pelayanan di bidang Kartu Tanda Penduduk dalam meningkatkan kepuasan pada masyarakat.

\section{DAFTAR PUSTAKA}

\section{Buku:}

Handoko, T.Hani. 1995. Manajemen. Edisi ke-2. BPFE. Yogyakarta

Hasibuan, S.P Malayu. 2000. Manajemen Dasar, Pengertian dan Masalah. Bumi Aksara. Jakarta

Herdiansyah, Haris. 2012. Metode Penelitian Kualitatif. Salemba Humanika. Jakarta

Mangkunegara,A.A Anwar Prabu. 2005. Evaluasi Kinerja Sumber Daya Manusia. Refika Aditama. Bandung

Moenir, H.A.S. 2010. Manajemen Pelayanan Umum di Indonesia. Bumi Aksara. Jakarta

Moleong, Lexy J. 2007. Metodologi Penelitian Kualitatif. Remaja Rosdakarya. Bandung

Nasution.2004.Manajemen Jasa Terpadu.Bogor:Ghalia Indonesia

Pasolong, Harbani. 2010. Teori Administrasi Publik. Bandung. Alfabeta

Ratminto dan Atik Septi Winarsih. 2012. Manajemen Pelayanan. Yogyakarta: Pustaka Belajar

Duadji,Noverman.2013. Manajemen Pelayanan Publik (Wacana Konsep, Teori dan Problema Pelayanan Publik). Bandar Lampung :

Universitas Lampung

Samsudin, Sadili. 2010. Manajemen Sumber Daya Manusia. Pustaka Setia. Bandung

Simamora, Henry. 2004. Manajemen Sumber Daya Manusia, Edisi ke-3. Penerbit BP.STIE YKPN. Yogyakarta

Sinambella, Lijan P dkk.2008.Reformasi Pelayanan

Publik.Jakarta:Bumi Aksara

Sugiyono. 2011. Metode Penelitian Kuantitatif kualitatif dan R\&D:

Bandung: Alfabeta 
Soekanto, 1986 . Metode Penelitian Hukum, UI Press Jakarta

Sutrisno, Edy . 2013 . Manajemen Sumber Daya Manusia. Kencana. Jakarta

Wibowo. 2011. Manajemen Kinerja. PT. Rajagrafindo. Jakarta

Hadikusuma, 1995 Metode Pembuatan Kertas Kerja atau Skripsi Ilmu Hukum. Bandung : Mandar Maju.

Budiono, 2003, Pelayanan Prima Perpajakan. Jakarta: PT. Rineka Cipta.

\section{Peraturan:}

Peraturan Pemerintah Nomor 73 Tahun 2005 tentang Kelurahan.

Peraturan Pemerintah Nomor 53 Tahun 2010 tentang Disiplin Pegawai Negeri Sipil

Peraturan Menteri Dalam Negeri Nomor 5 Tahun 1991 tentang Pelaksanaan Administrasi Pemerintahan Kelurahan.

Peraturan Menteri Dalam Negeri Nomor 12 Tahun 2007 tentang Profil Desa dan Kelurahan.

Peraturan Daerah Kabupaten Mamasa Nomor 4 Tahun 2001 tentang Pembentukan, Penghapusan, dan Penggabungan Kecamatan dan Kelurahan dalam Kabupaten Mamasa.

Peraturan Daerah Kabupaten Mamasa Nomor 8 Tahun 2008 tentang Kelurahan.

Peraturan WaliKabupaten Mamasa Nomor 32 Tahun 2008 tentang Tugas, Fungsi dan Tata Kerja Kelurahan dan Kecamatan Kabupaten Mamasa.

Peraturan Menteri Dalam Negeri Nomor 12 Tahun 2007 tentang Profil Desa dan Kelurahan

Peraturan Pemerintah Nomor 72 Tahun 2005 tentang Desa

Peraturan Walikota Kabupaten Mamasa Nomor 31 Tahun 2008 tentang Tugas, Fungsi dan Tata Kerja Kecamatan Kabupaten Mamasa Undang-Undang Nomor 6 Tahun 2014 Tentang Desa dan Peraturan Pelaksanaanya 
Richard

Undang-Undang Nomor 32 Tahun 2004 tentang Pemerintahan Daerah.

86 MITZAL (Demokrasi, Komunikasi, dan Budaya):

Jurnal Ilmu Pemerintahan \& Ilmu Komunikasi 